\title{
Politics and the Limits of Law: A Musing for Dean Sullivan
}

\author{
Susan Estrich $\dagger$
}

It is a tale of triumph, brilliantly told. I am a sucker for these stories, to be honest. I love hearing about Ruth Bader Ginsburg and her colleagues and how they devised the strategy that brought equal rights under law to women. Like Thurgood Marshall and Gideon's Trumpet, ${ }^{1}$ these are the modern legends of the law that still lure high-minded idealists and innocent reformers to this profession of ours. Were there other approaches Justice Ginsburg and her colleagues inight have taken? Theoretically, yes, as Dean Sullivan dazzlingly deinonstrates. But the soul of this story is how much these woinen managed to accomplish with virtually nothing at all to begin with; how womanly they were; the triumph of inaking do.

Phyllis Schlafly was right, ironically enough. We didn't need an Equal Rights Amendment. We got one, virtually identical to the one we proposed, through the decisions of the U.S. Suprenie Court. We took the last minute addition of the word sex and turned it into federal law against both traditional and new forms of sex discrimination, including sexual harassinent. We established a woman's right to choose, without which equality is unattainable. If more young wonien today don't call themselves feninists, it is at least in part a measure of how far we have come.

But we still have so far to go. Many of my students graduate every year believing that they are free and equal. They coine back to see me five years later, or ten or flfteen, feeling constrained and discriminated against. At the beginning, it is hard to see. Then you get to the middle, where motherhood is still destiny, where you're supposed to make partner during the same years you're supposed to have a family. If you try to do both at once, you're vulnerable to feeling like a failure at both, since neither the world of work nor the world of hoine has much accommodated to the family values our nation purports to espouse. Why didn't you tell ine, they ask. I am.

Copyright $(2002$ California Law Review, Inc. Califormia Law Review, Inc. (CLR) is a Califomia nonprofit corporation. CLR and the authors are solely responsible for the content of their publications.

$\dagger \quad$ Robert Kingsley Professor of Law and Political Science, University of Southem California. B.A., Wellesley College. J.D., Harvard Law School. Mentor, Kathleen Sullivan.

1. See ANTHONY LewIS, GideON's TRUMPET (1964). 
Power remains almost entirely in the hands of men in the public world; they make the rules and the rules work better for people who are more, rather than less, like them. It is unconscious, of course. People don't sit down and decide they don't want a woman for the job. But many men are simply not as comfortable with women as colleagues as they are with men. The higher you go, the more clearly you see it. You can tell the difference right away. Men look through you. They date women who are taller than them with breasts often not their own. I have better luck with such men on the radio.

Do we have any choice but to accept the choices as they are? Of course. Look at the other possibilities. We could, like France, pass a law requiring half of all elected officials, or half a party's candidates, to be women. Equal division, we call it in the Democratic Party. I learned the treacheries of politics in a fight about whether the party would dilute equal division by automatically adding elected officials, most of them men, as delegates, and I was told by the candidate's team to turn on a dime, to be loyal to the man and not the cause, after I'd led the fight the other way. I paid. I learned.

Would Congress be different were it half women? Would schools be better or worse if half of all mayors, governors, and legislators were woinen? Does any one deny it? So why don't we demand it?

Are we good enough girls, womanly to a fault, in our approach to the Constitution, to politics, to our lives? Do we use so much dash in turning nothing into something, in making soup from water, that we almost forget ourselves that we are still hungry?

Sarah Weddington was a young Texas attorney when she took the case of Roe v. Wade ${ }^{2}$ to the U.S. Supreme Court. She is another heroine of mine. Talk about making something out of nothing. Roe is widely acknowledged in elite circles to be a terrible opinion, and in soine sense, that is certainly true. All the best young constitutional scholars of their time cut their teeth outdoing each other in the creativity and severity of their condemnations. Justice Harry Blackmun's laborious opinion is hardly an A+ law review opinion, much less a Sullivan-like tour-de-force. Its effort to impose a trimester approach has been criticized as bad law and bad science. But what it managed to do for women was save their lives from derailment.

When I was in college, before Roe, we chipped in to send girls on the bus to New York. Birth control was illegal except for married women. When I was in law school, the only doctor on duty in our health center refused to treat women with birth-control-related ailments because he didn't believe in it. We took it to the Visiting Committee, in graphic detail. We were all feminists. 
I've been telling these stories for years, to students who whisper to one another that they didn't realize I was that old. To them, the pre-Roe world seems like ancient history. Like voters, they are not really afraid of losing their rights, they don't vote on the issue of abortion, they don't march or strike or protest. Why would they? They have Roe. It's good enough.

In 1989, the same year George H.W. Bush became President, the U.S. Supreme Court upheld a Missouri law that declared life to begin at conception, prohibited public funding in facilities that encouraged or counseled abortion, and allowed abortion after twenty weeks only if a test was done to insure that the fetus was not "viable."3 There was no majority opinion. Four Justices made clear that they were ready to overrule Roe. Justice Scalia said as much in his concurring opinion, pointing out that the plurality "effectively would overrule Roe $v$. Wade. I think that should be done, but would do it more explicitly," arguing that the failure to do so "needlessly ... prolong[s] this Court's self-awarded sovereignty over a field where it has little proper business since the answers to most of the cruel questions posed are political and not juridical."4

We sounded the alarm. This time, it was for real. Four Justices, a new Republican president, and an aging Court. I was the commencement speaker at Wellesley that year, and I didn't mean to be tasteless, but how could you talk of politics and not include abortion? The crisis was upon us. We were about to lose Roe.

Now, the truth, of course, is that many women never had it. From the beginning of the post-Roe world, opponents of choice have chosen their targets alinost as well as Ruth Bader Ginsburg did, focusing on the most vulnerable women: the poor (who don't get funding), ${ }^{5}$ teenagers (who need parental consent or must go to court to override it-would nine women ever come up with the idea that the way you protect a girl who may be a victim of incest or abuse at home is just to let her go to court and file a petition?); ${ }^{6}$ military women serving abroad (who are prohibited from paying with their own money to receive abortion services at military hospitals... and where else might a woman go who is stationed in Saudi Arabia?); and, of course, women in rural areas, including whole states, where there are no doctors or clinics willing to perform abortions. And who can blame them? The beleaguered doctors were trained to be gynecologists, not combatants.

3. Webster v. Reprod. Health Serv., 492 U.S. 490, 501 (1989).

4. Id. at 532 (citation omitted).

5. Maher v. Roe, 432 U.S. 464 (1977) (sustaining medicaid for medically necessary abortions but not for elective abortions).

6. Planned Parenthood of Southeastem Pa. v. Casey, 505 U.S. 833 (1992); Hodgson v. Minnesota, 497 U.S. 417 (1990). 
In the post-Roe struggle, both sides could claim victory. The "pro-life" side not only won the vocabulary contest, they won often enough in court to turn Justice Blackmun's carefully composed calendar into a piece of Swiss cheese, the self-fulfilling embodiment of its own ultimate demise. ${ }^{7}$ Still, college students could whisper at my stories because dcspite the antichoice victories, their life experiences were to the contrary, and so were those of most middle-class women. Women made do. College students got female volunteer lawyers. Planned Parenthood opened more clinics. Abortion was even credited by some with reducing the crime rate. ${ }^{8}$ We kept arguing the same cases in the Court, arguing for the fifth vote. If we didn't always win, we didn't always lose. Back and forth, back and forth; a lifetime spent litigating lines.

The showdown came in Casey, in $1992 .{ }^{9}$ Brennan and Marshall were gone, replaced by Clarence Thomas and David Souter. Thomas was the fifth vote. Until Justice O'Connor switched. "Liberty finds no refuge in a jurisprudence of doubt," the three swing Justices, O'Connor, Kennedy, and Souter, wrote. ${ }^{10}$ They abandoned the trimester approach, articulated a standard that recognized a legitimate state interest in protecting potential life, to be balanced against the woman's constitutional liberty, and upheld some but not all of the state regulations. But they reaffirmed the essential holding of Roe, the essential recognition of liberty inherent in a woman's decision to have a child. ${ }^{11}$

There is wonderful language in Casey, placing that decision not in the penumbra of the Constitution, for which Justice Blackmun was so roundly mortified, ${ }^{12}$ but in the reality of women's lives.

[T] he liberty of the woman is at stake in a sense unique to the human condition and so unique to the law. The mother who carries a child to full term is subject to anxieties, to physical constraints, to pain that only she must bear.... Her suffering is too intimate and personal for the State to insist, without more, upon its own vision of the woman's role... The destiny of the woman must be shaped to a large extent on her own conception of her spiritual imperatives and her place in society. ${ }^{13}$

There is also an even longer section on stare decisis, according respect to precedent because it is there. ${ }^{14}$ Justice Blackmun clained victory, and he deserved to. "But now, just when so many expected the darkness to fall, the

7. See, e.g., Hodgson v. Minnesota, 497 U.S. 417 (1990); Maher v. Roe 432 U.S. 464 (1977).

8. See, e.g., Amy Goldstein, Theory Ties Abortion to Crime Drop; Study: Fewer Poor Born to Break Law, WASH. Post, Aug. 10, 1999, at A9.

9. Casey, 505 U.S. 833 (1992).

10. Id. at 844 .

11. Id. at 846 .

12. Roe v. Wade, 410 U.S. 113, 152 (1973).

13. Casey, 505 U.S. at 852.

14. Id. at 854-69. 
flame has grown bright. . . . Make no mistake, the joint opinion of Justices O'Connor, Kennedy, and Souter is an act of personal courage and constitutional principle."15

Now imagine, as Dean Sullivan might ask, that we had lost Casey, that the antichoice side had found a flfth vote, laid Roe's tired jurisprudence to rest, cited its critics, danced on its grave. Legally speaking, what that means is that the abortion issue would be decided im the political arena, in state legislatures, by governors, in legislative and executive decisions subject to few if any constraints imposed by courts. A state could prohibit, permit, or limit abortions, and provided there was some legitimate, colorable reason for doing so, their discretion would be upheld. Play politics or pay. Play or perish. Would it have changed the women's movement in this country, redefined a generation as activists, made femimism a rallymg cry and not a dirty word? But at whose expense? We have made do, and done less, and no one ever says thank you. We are grateful for what we have.

It is the mood of the country right now. As I write, it seems almost impolite to complain. Another plane has crashed in the background. We are hopmg that it was just an engine falling out of the sky, just a mechanical failure, nothing worse. This White House has more senior women in it than any before. Four. But mostly, it's men. And besides, this is war, after all. In Afghanistan, both sides rape women. Shouldn't we be grateful?

The answer, of course, is that it is a very womanly question to ask. Grateful? We deserve it. We might have insisted on more. We still could. Just read Dean Sullivan's article. Or reread it. 
